\title{
Flow Control around a Circular Cylinder by a Small Rod
}

\author{
Takayuki Tsutsui \\ National Defense Academy of Japan, Department of Mechanical Engineering, \\ 1-10-20 Hashirimizu, Yokosuka, Kanagawa, 238-8686, Japan \\ e-mail: tsutsui@nda.ac.jp
}

\begin{abstract}
Several control methods for the flow around a bluff body have been proposed in previous studies. One such method is the forced reattachment method, which is a type of separated shear layer control that uses a small rod. The small rod is placed in the optimal position on the shear layer from a circular cylinder, thus dividing the shear layer into upper and lower parts. The upper shear layer is supported and elongated by the small rod, and the lower shear layer reattaches and adheres to the rear side of the cylinder. A large stagnant region forms behind the cylinder. This method reduces drag and generates a lift, and is promising for bluff body flow control. However, the forced reattachment phenomenon occurs only under certain conditions. The aim of the present study was to clarify the rod position and diameter required for forced reattachment.
\end{abstract}

\section{Keywords}

Circular cylinder; Flow control; Drag reduction; Fluid force; Flow visualization.

\section{Introduction}

Forced reattachment has been reported in previous papers as a unique flow control method [1-5]. Figure 1 (a) is a flow visualization photograph demonstrating this phenomenon. Figure 1 (b) shows a schematic of the forced reattachment phenomenon. A small rod is positioned on the shear layer separated from the upper side of a circular cylinder. In this setup, the upper shear layer is supported and elongated by the small rod, and the lower shear layer reattaches and adheres to the rear side of the cylinder. A large stagnant region forms behind the cylinder. This forced reattachment phenomenon is not an intermittent phenomenon, and the wake motion is thus not active than that of a single circular cylinder [5].

Applying this control method, a drag is reduced and a lift force is generated. These facts regarding the forced reattachment phenomenon have been numerically simulated in a previous study [3]. Recently, the instantaneous characteristics of this method have been reported [5].

The forced reattachment phenomenon occurs only under certain conditions. The aim of this study was to elucidate these conditions, which are related to the position and diameter of the small rod. This paper presents the effect of the position and diameter of the small rod and a mathematical representation of the condition for forced reattachment.

\section{$1 \quad$ Experimental Device and Methods}

The coordinate systems and notation used in the present study are shown in Figure 2. The diameter $\mathrm{D}$ of the circular cylinder was $40 \mathrm{~mm}$, and the diameter $\mathrm{d}$ of the small rod was varied from 2 to $18 \mathrm{~mm}$. The gap $G$ between the cylinder and small rod was varied from 2 to $7 \mathrm{~mm}$. The angular position $\alpha$ of the rod was varied from $90^{\circ}$ to $180^{\circ}$. 
Experiments were carried out in a low-speed wind tunnel, the working section of which has a height of $1,000 \mathrm{~mm}$, a width of $150 \mathrm{~mm}$, and a length of 1,200 $\mathrm{mm}$. The free-stream velocity $U$ was varied from 6 to $20 \mathrm{~m} / \mathrm{s}$, and the turbulent intensity was approximately $0.4 \%$ in this velocity range. The Reynolds number based on $D$ ranged from $1.6 \times 10^{4}$ to $6.3 \times 10^{4}$. In the experiment, $d, G$, and $\alpha$ were systematically changed, and the surface pressure of the circular cylinder and the vortex shedding frequency were measured. The drag and lift coefficients were obtained by integrating the pressure distribution. The vortex shedding frequencies behind the circular cylinder were obtained from frequency analysis of the velocity fluctuation of an I-type hot-wire anemometer. Flow visualization was conducted using a smoke tunnel.

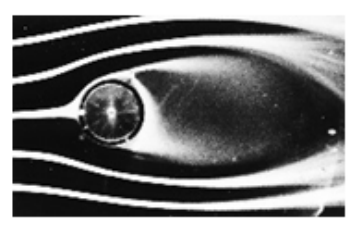

(a) Flow visualization ( $\mathrm{D}=40 \mathrm{~mm}, \mathrm{~d}=2 \mathrm{~mm}$, $\mathrm{G}=6 \mathrm{~mm}, \alpha=121^{\circ}, \mathrm{Re}=1.6 \times 10^{4}$ )

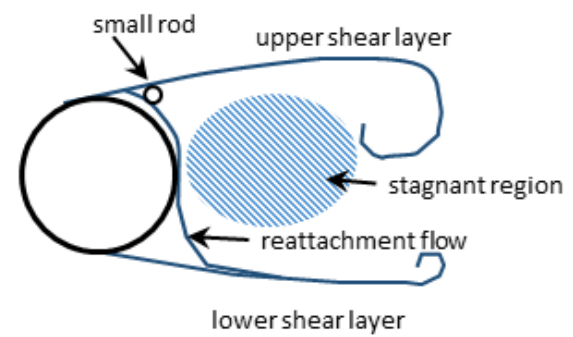

(b) Schematic of the forced reattachment phenomenon ${ }^{(5)}$

Fig. 1: Forced reattachment.

\section{Fig. 2: Coordinate system and notation.}

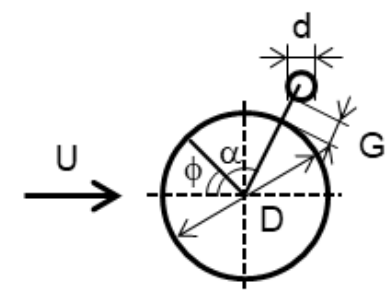

\section{$2 \quad$ Results and Discussion}

\subsection{Flow Patterns}

Typical flow patterns are presented in Figure 3. It shows the pressure distributions and flow visualization photographs for several angular positions of the small rod. The open circle and the dotted line indicate the pressure distribution of the cylinder with and without small rod respectively. Two types of photographs, a long exposure (1 $\mathrm{s})$ photograph and an instantaneous exposure photograph, are included in Figure 3.

At $\alpha=115^{\circ}$, the small rod was outside of the separated shear layer from the circular cylinder and had little effect on the pressure distribution.

At $\alpha=121^{\circ}$, the forced reattachment phenomenon occurred. The separated shear layer was divided by the small rod, and the lower side of the shear layer reattached at the rear face of the cylinder. In this case, the value of $C p$, pressure coefficient, near the separation point at approximately $\phi=75^{\circ}$ was much lower than that in the pressure distribution with no rod. The value of $C p$ then increased suddenly and reached a local maximum in the range of $\phi=145^{\circ}$ to $150^{\circ}$ because the flow through the gap was accelerated to 1.6 times the free stream velocity and separated under these conditions [4]. The value of $C p$ on the rear lower face of the cylinder was higher than that in the case of the lone cylinder because of the stagnant region near the rear lower side of the cylinder. 

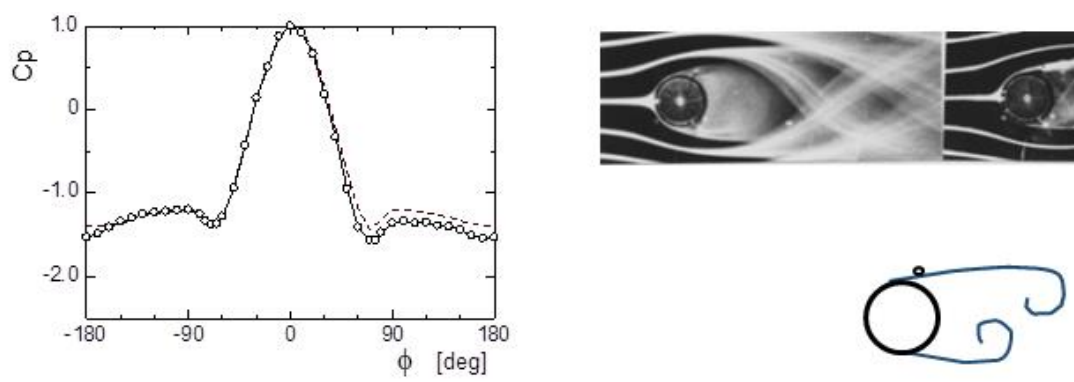

(a) $\alpha=115^{\circ}$
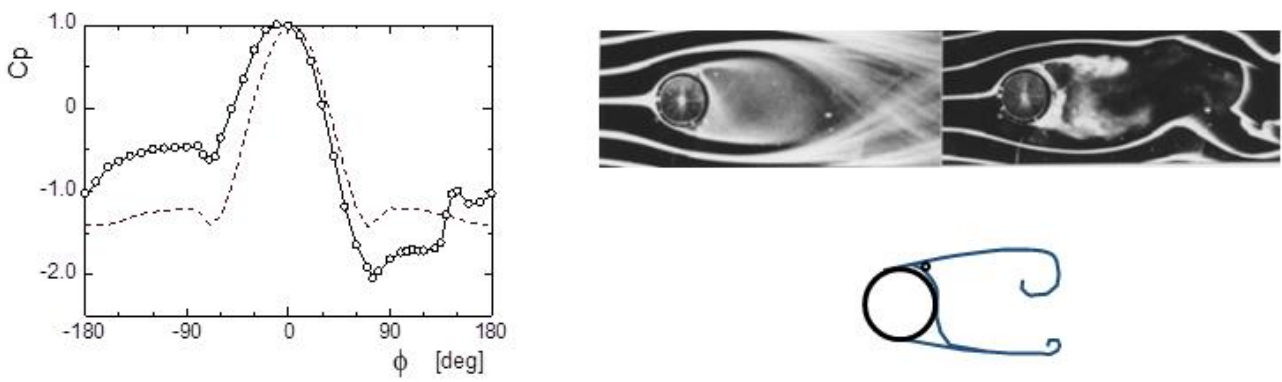

(b) $\alpha=121^{\circ}$
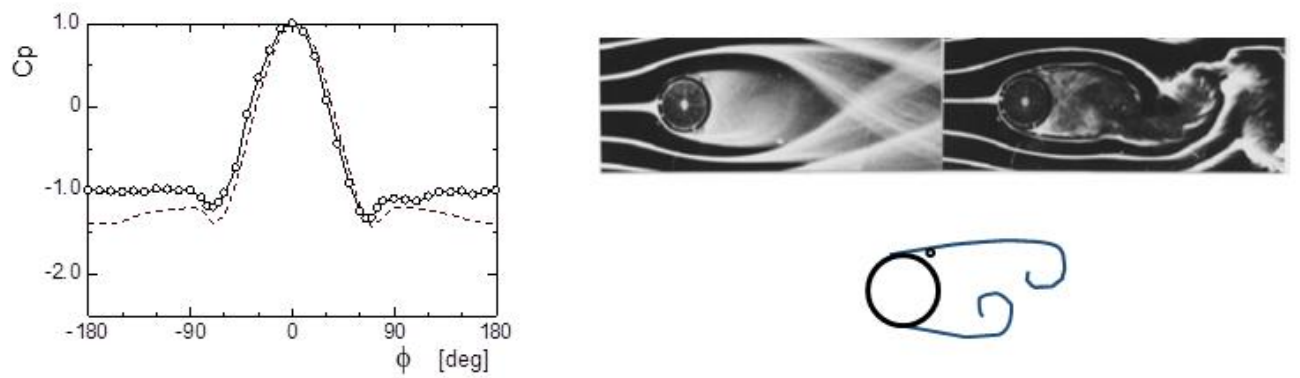

(c) $\alpha=124^{\circ}$
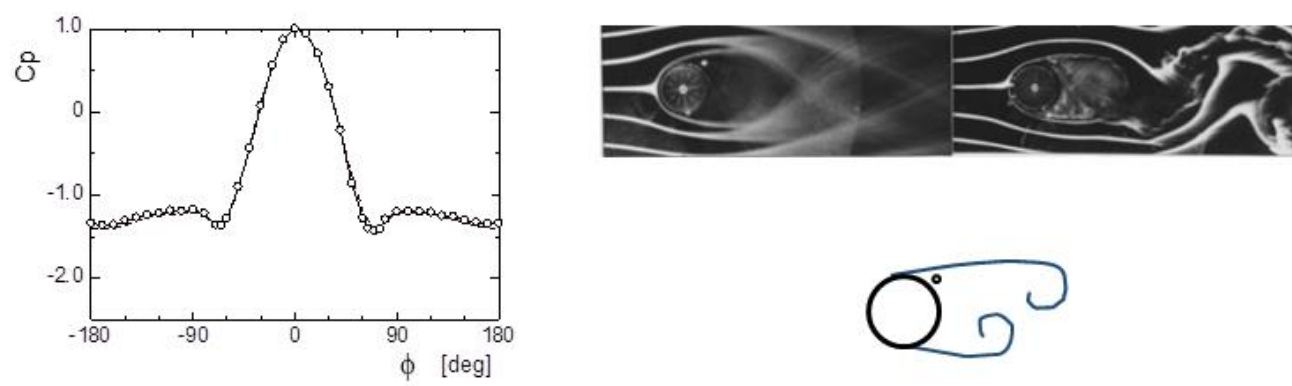

(d) $\alpha=130^{\circ}$

Fig. 3: Flow pattern, pressure distribution and flow visualization photograph at different value of $\alpha\left(D=40 \mathrm{~mm}, d=2 \mathrm{~mm}, G=6 \mathrm{~mm}, \operatorname{Re}=4.2 \times 10^{4}\right)$

At $\alpha=124^{\circ}$, the small rod was located just inside the separated shear layer. The forced reattachment phenomenon did not occur, but the separated shear layer was elongated by the support of the small rod. This phenomenon has been described in previous papers $[1,2]$. The value of $C p$ on the rear face was higher than that of the lone circular cylinder.

At $\alpha=130^{\circ}$, the small rod was inside the separated shear layer and had little effect on the pressure distribution.

The features of the flow patterns are shown in Figure 4. The drag coefficient $C_{D}$, the lift coefficient $C_{L}$, and the Strouhal number St are plotted against $\alpha$ in Figure 4. The Strouhal 
number is defined as $S t=f D / U$, where $\mathrm{f}$ is the frequency of vortex shedding from the cylinder. Under the conditions $d=2 \mathrm{~mm}$ and $G=6 \mathrm{~mm}$, forced reattachment occurred at $\alpha=$ $121^{\circ}$. In this case, $C_{D}$ and $C_{L}$ reached their minimum and maximum recorded values in the range $\alpha=122^{\circ}$ to $124^{\circ}$. The change in St with $\alpha$ was dramatic. In the range $\alpha=90^{\circ}$ to $110^{\circ}$, vortex shedding was suppressed by the small rod. At $\alpha=121^{\circ}$, the value of $S t$ decreased as a result of forced reattachment. Just after that, at $\alpha=124^{\circ}, S t$ increased; at this position, forced reattachment did not occur, but the upper separated shear layer was elongated by the support of the small rod, causing the vortex shedding frequency to increase. When $\alpha$ was increased further, St took a constant value of 2.05 , which is standard $S t$ value for single circular cylinder.
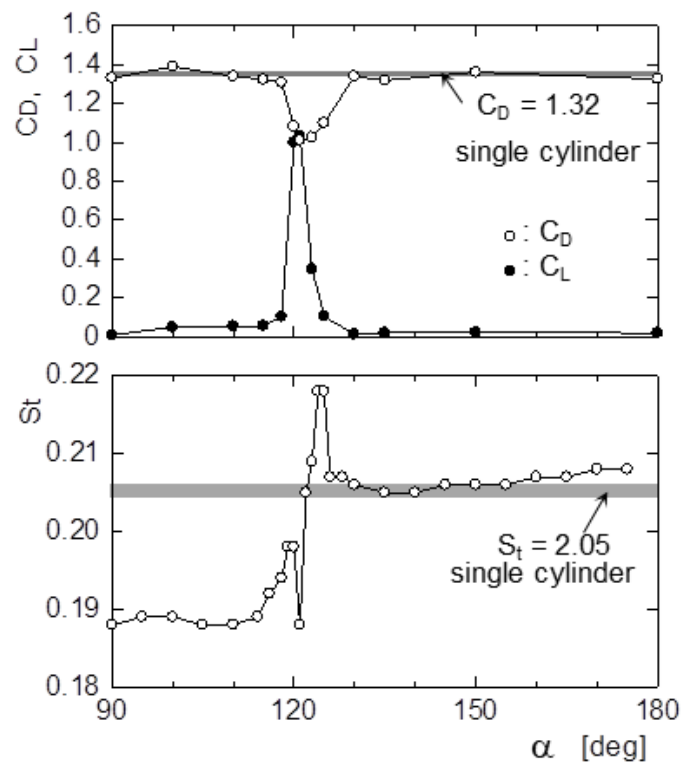

Fig. 4: Drag, lift and Strouhal number plotted against the angular position of the small rod $\left(D=40 \mathrm{~mm}, d=2 \mathrm{~mm}, G=6 \mathrm{~mm}, R e=4.2 \times 10^{4}\right)$

\subsection{Effect of Rod Diameter}

The forced reattachment phenomenon occurred with several small rods of different diameters. Figure 5 shows the pressure distributions and flow visualization photographs for $d=6,10$, and $18 \mathrm{~mm}$. The open circle and the dotted line indicate the pressure distribution of the cylinder with and without small rod respectively.

For $d=6$ and $10 \mathrm{~mm}$, the pressure distributions were similar and had features similar to the case with $d=2 \mathrm{~mm}$ shown in Fig. 3 (b).

For $d=18 \mathrm{~mm}$, the pressure distribution was different from that for $d=2,6$, and $10 \mathrm{~mm}$. From $\phi=30^{\circ}$ to $120^{\circ}$, the value of $C p$ was higher than that in the case of single circular cylinder and with $d=2,6$, and $10 \mathrm{~mm}$ because the separated shear layer was dammed by the small rod. Furthermore, from $\phi=-180^{\circ}$ to $-60^{\circ}$, the value of $C p$ was lower than those in the other cases. On the basis of this pressure distribution, a reduced drag and the generation of lift cannot be expected. In this case, the forced reattachment phenomenon occurs intermittently intermittently [3]; that is, its occurrence is unstable.

Figure 6 shows the effect of the small rod diameter on the drag and lift coefficients. The value of $C_{D}$ was approximately 1.1 and remained almost constant from $d / D=0.04$ to 0.25 ; over $d /$ $D=0.25$, the value of $C_{D}$ increased with increasing $d / D$. At $d / D=0.45$, the value of $C_{D}$ was 1.6, which exceeds that of single circular cylinder. The value of $C_{L}$ decreased with 
increasing $d / D$. At $d / D=0.45$, the value of $C_{L}$ was negative. These results indicate that there is an optimal rod size for forced reattachment.
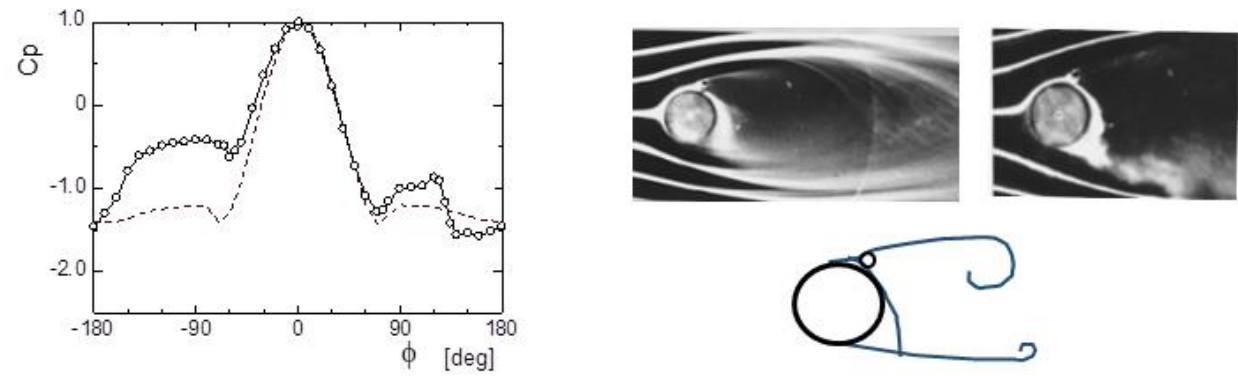

(a) $\mathrm{d}=6 \mathrm{~mm}, \mathrm{G}=5 \mathrm{~mm}, \alpha=113^{\circ}$
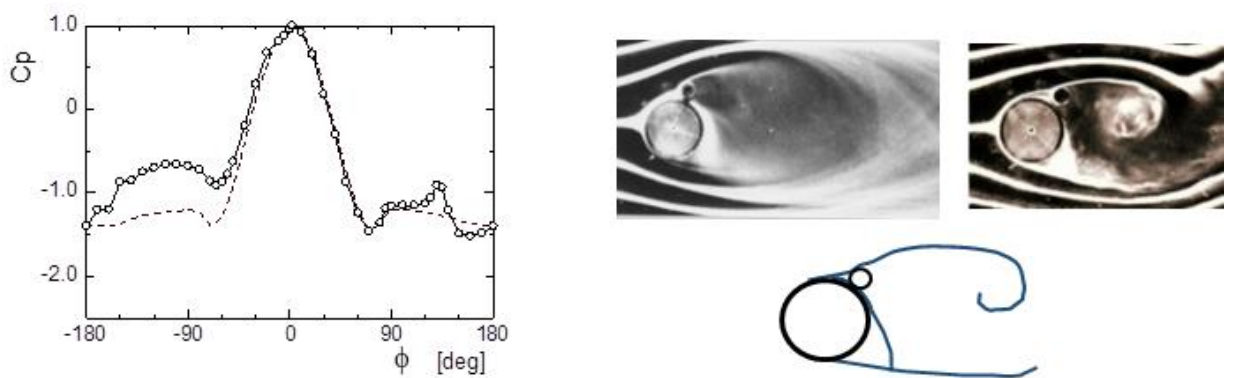

(b) $\mathrm{d}=10 \mathrm{~mm}, \mathrm{G}=4 \mathrm{~mm}, \alpha=112^{\circ}$
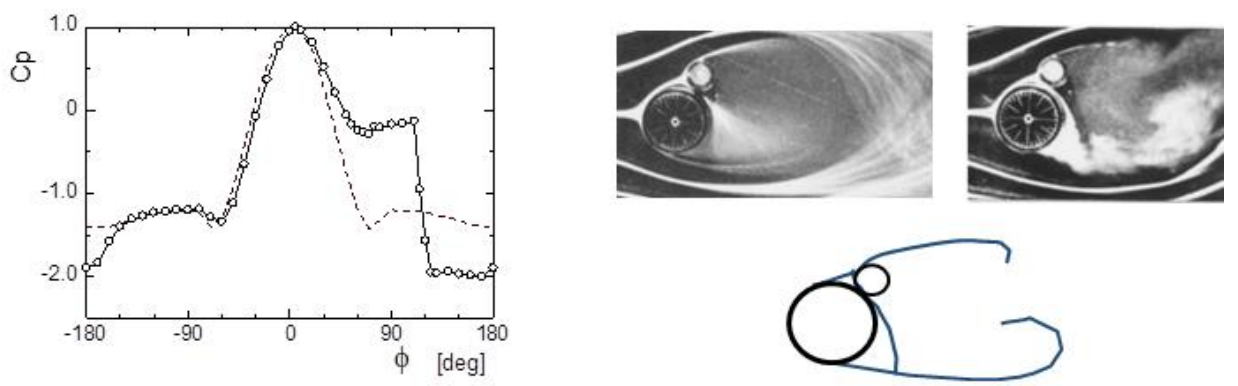

(c) $\mathrm{d}=18 \mathrm{~mm}, \mathrm{G}=2.5 \mathrm{~mm}, \alpha=120^{\circ}$

Fig. 5: $\quad$ Effect of small rod diameters $\left(D=40 \mathrm{~mm}, \mathrm{Re}=4.2 \times 10^{4}\right)$

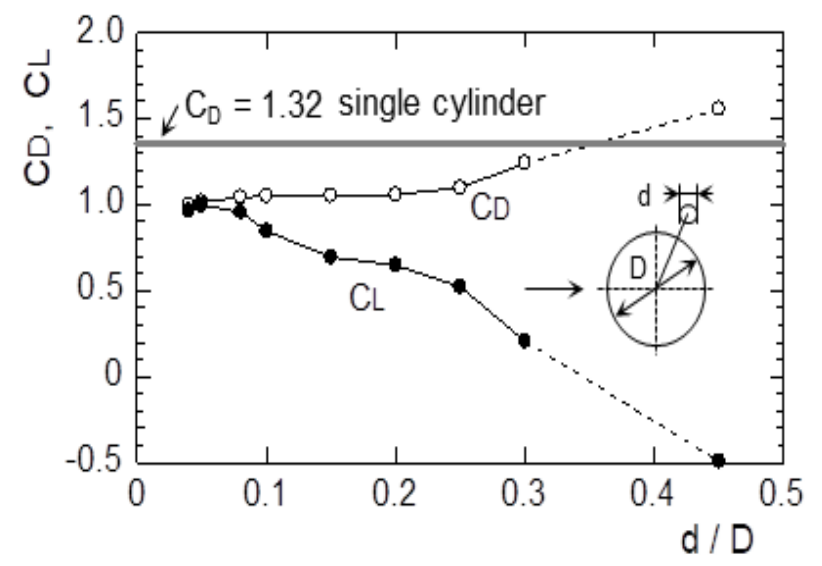

Fig. 6: Effect of rod diameter on drag a lift coefficients 


\subsection{Optimal Conditions for Forced Reattachment}

Figure 7 shows the small rod positions at which the forced reattachment phenomenon occurs. The dotted line indicates the separated shear layer obtained from the photograph of the lone circular cylinder. The open circles show the positions and sizes of the small rod. For forced reattachment to occur, the small rod must be located along the dotted line.

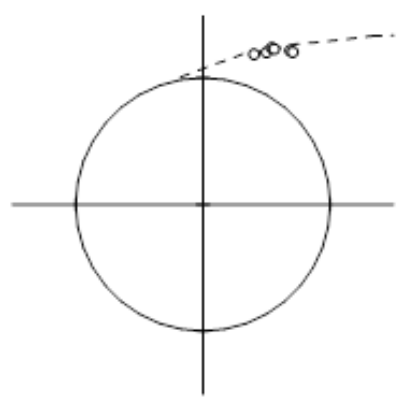

(a) $\mathrm{d}=2 \mathrm{~mm}$

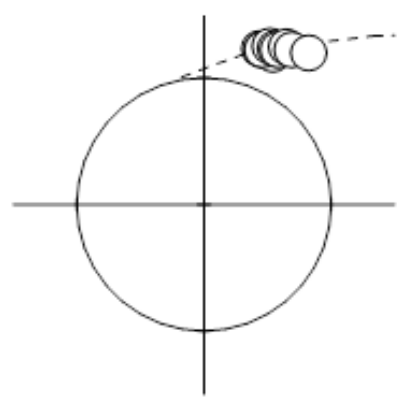

(b) $\mathrm{d}=6 \mathrm{~mm}$

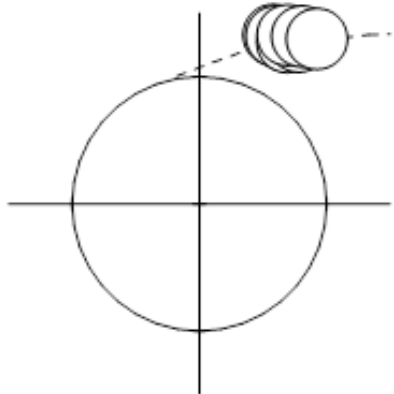

(c) $\mathrm{d}=10 \mathrm{~mm}$

Fig. 7: Location of the small rod

To derive a formula for the angular position $\alpha$, a simple analysis was performed. The separated shear layer was assumed to lie along the line tangent to the surface of the circular cylinder passing through the separation point, as shown in Figure 8.

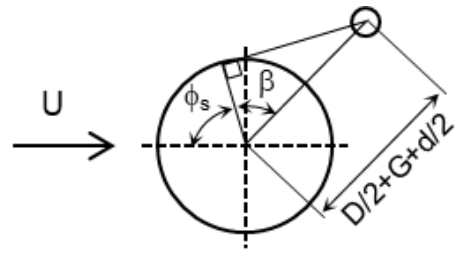

Fig. 8: Analysis of optimum rod position

The forced reattachment phenomenon occurs when the center of the small rod is on this tangent line. The angular position $\alpha$ was derived as function of $D, d$, and $G$ based on the separation point $\phi_{s}$ as

$$
\begin{gathered}
\alpha=\phi_{s}+\beta, \quad \phi_{s}=78^{\circ} \\
\cos \beta=(D / 2) /(D / 2+G+d / 2) \\
D=40 \mathrm{~mm}, d=2-10 \mathrm{~mm}, G=2-7 \mathrm{~mm} .
\end{gathered}
$$

Figure 9 shows the experimental data and the analytical lines for $\alpha$ at different values of $D, d$, and $G$. The open circles indicate the experimental conditions under which the forced reattachment phenomenon occurred, and the dotted lines represent the values of $\alpha$ obtained from Equations (1) and (2). The analytical form of $\alpha$ corresponds reasonably well with the experimental data. 


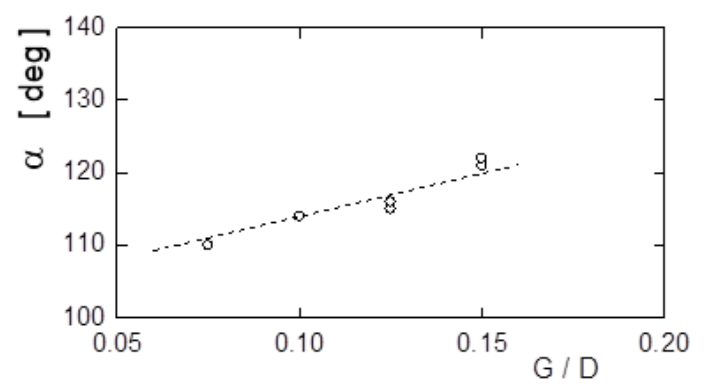

(a) $\mathrm{d}=2 \mathrm{~mm}$

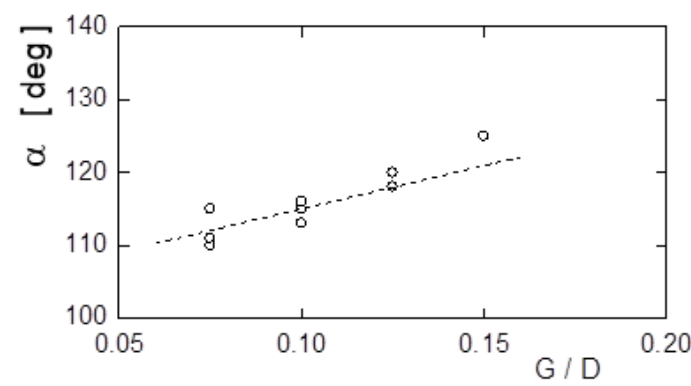

(b) $\mathrm{d}=6 \mathrm{~mm}$

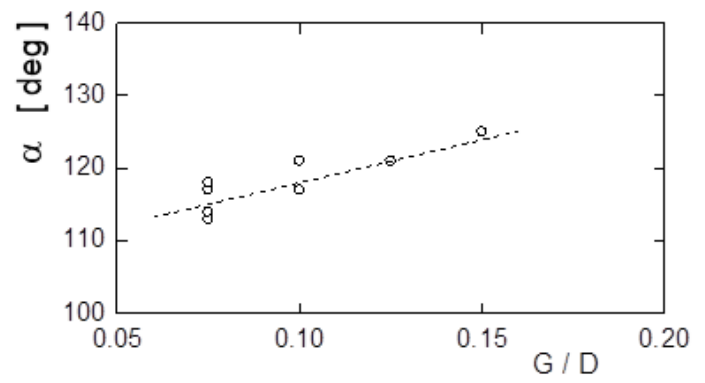

(c) $\mathrm{d}=10 \mathrm{~mm}$

Fig. 9: Optimal rod position

\section{Conclusions}

A unique flow control method, the forced reattachment method, was considered in this study. The features of this phenomenon, the effect of the rod size, and the optimal rod size and position were investigated. An equation that can be used to determine the conditions required for occurrence of the forced reattachment phenomenon was successfully derived. The equation was found to be reasonably well with the experimental data. However, if the diameter of the rod is large, reduced drag and the generation of lift cannot be expected.

\section{Literature}

[1] IGARISHI, T.; TSUTSUI, T.: Flow Control around a Circular Cylinder by a Small Cylinder. In: Proceedings of the $11^{\text {th }}$ Australasian Fluid Mechanics Conference. Hobart, Australia, 1992, pp. 519-522.

[2] IGARASHI, T.; TSUTSUI, T.: Flow Force Acting on a Circular Cylinder Controlled by a Small Rod. In: Proceedings of the $3^{\text {rd }}$ JSME-KSME Fluids Engineering Conference. Sendai, Japan, 1994, pp. 571-576.

[3] TSUTSUI, T.; IGARASHI, T.; KAMEMOTO, K.: Interactive flow around two circular cylinders of different diameters at close proximity. Experiment and numerical analysis by vortex method. Journal of Wind Engineering and Industrial Aerodynamics. 1997, Volumes 69-71, pp. 279-291. DOI: 10.1016/S0167-6105(97)00161-X 
[4] TSUTSUI, T.; IGARASHI, T.: Flow control around a circular cylinder by a small cylinder (Properties of reattachment jet). In: Proceedings of the $3^{\text {rd }}$ ASME-JSME Joint Fluids Engineering Conference. San Francisco, California, FEDSM'99-6943, 1999.

[5] TSUTSUI, T.: Instantaneous fluid force acting on a circular cylinder control by a small rod. EPJ Web of Conferences. 2018, Vol. 180, Paper No. 02110. DOI: $10.1051 /$ epjconf/201818002110 


\section{OVLÁDÁNÍ PRŮTOKU KOLEM KRUHOVÉHO VÁLCE MALOU TYČÍ}

$\mathrm{V}$ předchozích studiích bylo navrženo několik kontrolních metod pro tok kolem oblého tělesa. Jednou z takových metod je metoda nuceného opětovného přiřazení, což je typ separátního řízení smykové vrstvy, která používá malou tyč. Malá tyč je umístěna v optimální poloze na smykové vrstvě z kruhového válce, čímž se rozděluje smykovou vrstvu na horní a dolní část. Horní smyková vrstva je nesena a prodloužena malou tyčí, a spodní smyková vrstva se připojí a přilne k zadní straně válce. Za válcem se tvoří velká stojatá oblast. Tato metoda snižuje tah a vytvárí zdvih a pomáhá řízení toku kolem oblého tělesa. Avšak fenomén nuceného opětovného prripojení nastává pouze za určitých podmínek. Cílem této studie bylo objasnit polohu a průměr tyče potřebné pro nucené opětovné nasazení.

\section{STEUERUNG DER DURCHFLUSSMENGEN UM DIE KRESIWALZE DURCH EINE KLEINE STANGE}

In den vorangegangenen Studien wurden einige Kontrollmethoden für den Fluss um einen runden Körper entworfen. Eine dieser Methoden ist die Methode der gezwungenen wiederholten Zuordnung, was einen Typ der separaten Steuerung der Rutschschicht darstellt, welche sich einer kleinen Stange bedient. Die kleine Stange wird in einer optimalen Position auf der Rutschschicht aus der Kreiswalze heraus gelagert, wodurch die Rutschschicht in einen oberen und einen unteren Teil geteilt wird. Die obere Rutschschicht wird getragen und verlängert von der kleinen Stange, und die untere Rutschschicht schmiegt sich an die hintere Seite der Walze an. Hinter der Walze bildet sich ein großer stehender Bereich. Diese Methode vermindert den Zug und schafft eine Hebung und hilft der Steuerung des Flusses um den runden Körper herum. Aber das Phänomen der gezwungenen wiederholten Anbindung tritt nur unter bestimmten Bedingungen ein. Ziel dieser Studie war die Klärung der Position und des Durchschnitts der Stange, welche für den erzwungenen wiederholten Einsatz notwendig ist.

\section{KONTROLOWANIE PRZEPŁYWU WOKÓŁ OKRĄGŁĘGO CYLINDRA PRZY POMOCY MAŁEGO DRĄŻKA}

W wyniku poprzednich badań zaproponowano kilka metod służących kontroli przepływu wokół okrągłego ciała. Jedną $\mathrm{z}$ takich metod jest metoda wymuszonego ponownego przyczepienia, będąca rodzajem oddzielonego kontrolowania warstwy ścinającej, wykorzystująca mały drążek. Mały drążek umieszczony jest w optymalnym położeniu w warstwie ścinającej okrągłego cylindra, w wyniku czego warstwa ta jest podzielona na część górną i dolną. Górna warstwa jest niesiona i zostaje przedłużona przez mały drążek a dolna warstwa przyczepia się do tylnej strony cylindra. Za cylindrem powstaje duży obszar stojącej cieczy. Metoda ta zmniejsza opór i powoduje unoszenie, pomagając w kontroli przepływu wokół okrągłego ciała. Zjawisko wymuszonego ponownego przyczepienia powstaje jednak tylko w pewnych warunkach. Celem opisywanych badań było wyjaśnienie położenia i średnicy drążka niezbędnych dla wymuszonego ponownego przyczepienia. 